$\xi=-1$

\title{
Evaluation of Drug Addicts Rate with Environmental Components Study in Terengganu, Malaysia
}

\author{
Mohd Ekhwan Toriman ${ }^{1}$, Mohd Khairul Amri Kamarudin ${ }^{2,3^{*}}$, Nur Atikah Mohd Adanan ${ }^{2}$, Norfatihah Haron', \\ Sharifah Nurul Izatiumira Syed Omar ${ }^{2}$, Wan Nur Ain Syazwani Wan Mohamad Zailani ${ }^{2}$, Nor Amira Shafiqah \\ Zulkifli $^{2}$, Siti Nor Fazillah Abdullah ${ }^{3}$ \\ ${ }^{I}$ Faculty of Social Sciences and Humanities, Universiti Kebangsaan Malaysia, 43600 Bangi, Selangor, Malaysia \\ ${ }^{2}$ Social Work Studies Centre, Faculty of Applied Social Science, Universiti Sultan Zainal Abidin, Gong Badak Campus, 21300 Kuala \\ Nerus, Malaysia \\ ${ }^{3}$ East Coast Environmental Research Institute (ESERI), Universiti Sultan Zainal Abidin, Gong Badak Campus, 21300 Kuala Nerus, Ma- \\ laysia \\ *Corresponding author E-mail: mkhairulamri@unisza.edu.my
}

\begin{abstract}
The evolution of drug addict's rate is significantly increase in Malaysia and it's became a chronic problem among the society. The number of drug addiction cases in Malaysia is contributed by the number of drug addicts involving all the states including Terengganu. The aim of this study is to evaluation the rate of drug addicts according to several environmental components which affects the increment of drug addiction in Terengganu. In this study, the Descriptive Statistics Analysis using XLSTAT has been use to describe the result. The results indicate there are five factors that involve with drug influence including peer influence, curiosity, depression, fun and enduring pain or body defense and the major factors influencing the involvement of drug addicts into this problem is peer influence. Therefore, the stakeholder involved could put an effort to reduce the drug addicts' rate through proving an effective plan. This study suggested all parties need to know the tremendous drug problem not only in Terengganu but also in Malaysia. This is so that the problem of drug can be reduced and make Malaysia a nation free from drug debris that can endanger everyone.
\end{abstract}

Keywords: Drug Addicts Rate; Addiction; Drug factors; district, gender; factor.

\section{Introduction}

Drugs are the largest criminal cases that have taken place from now on. The government has done a variety of ways to mitigate this problem. However, this problem remains as a threat to this country. Drug abuse is the most complicated social problem in the world faced by the state. This problem has started to be said since the 70's and until now there are no positive changes in effort to solve this problem [1]. Based on the National Institute on Drug Abuse (NIDA), it provides a comprehensive definition of drug addiction, stating, "Addiction is defined as a chronic, relapsing brain disease that is characterized by compulsive drug seeking and use despite harmful consequences." This addiction is one of the diseases in the part of the brain because it scientifically causes changes in the brain. The population of drug addicts in Terengganu are categorized by age and gender [2, 3]. Malaysia is an Islamic state ruled by Islamic religious authorities representing a safe country which consisting a population of courtesy, respect between the community and demands of the religion of Islam. Those who take drugs are probably caused by some factors including over-stress, have a big or small problems, influenced by western culture, religious education, peer pressure and more [4].

Parents have a very important role in educating their children well and expose their children to the dangers of taking drugs. There is a strong association between drug and criminal problems in which rising rates of drug-taking causing rising crime rates as well. In Malaysia, smuggling, distribution, drug abuse and addiction have become a very big issue which threatens the security state [5]. A scholar has discussed and gives a view that these smuggling activities happened almost every day in our country. The smuggling and drug distribution activities experienced a significant increase from day to day [6]. The success of smuggling syndicates across the border poses a threat to the integrity of the Malaysian's border. Illegal entry into this country is deemed as reversing the credibility of the country by showing that its borders cannot be controlled by effectively. Malaysia is also working with international agencies such as the eradication of United States to curb such activities, including management and enforcement aspects, so that we can avoid the inherent threat to national security. The threat of drugs in Malaysia has to do with international syndicates. Syndicates from Malaysia have been exporting drugs to Europe and after 30 years of syndication, Europe also export drugs to the countries in Asia [7, 8]. In Malaysia, there are two categories of distribution trends that contributed to the drug issue is the cause of national security threats. Trends include how the distribution of illegal drugs in Southeast Asia, namely, first, the traditional types of drug smuggling, while the second trend, the distribution of synthetic drugs $[5,9]$.

There are two things that involve the purpose of drug addiction but are not necessarily related. The first thing is; the drug is a chemical agent that affects biological function in animals and humans. There are a number of chemical agents that may be con- 
sidered as valid or invalid. Those who take drugs will experience psychological encouragement and physically in terms of impact on the health of the body $[10,11]$. For those who do not take excessive drug intentions with the optimum dose does not meet the definition of drug addiction. Based on National Institute of Drug Abuse (NIDA), addiction is defined as a chronic, relapsing brain disease that is characterized by compulsive drug seeking and use, despite harmful consequences. It is considered as a brain disease because drugs change the brain, they change its structure and how it works. These brain changes can be long-lasting, and can lead to the harmful behaviours seen in people who abuse drugs. It is also very chronic, relapsing disorder in which compulsive drug-seeking and drug-taking behaviour persist despite serious negative consequences $[12,13]$. The addictive drugs discussed here are opioids, cannabinoids, ethanol, cocaine, amphetamines, and nicotine.

According to social definition, drugs are whatever chemicals that when taken have psychological effects, chemistry and medicine [14]. Drugs can be taken positively if the individual is taking drugs for the purpose of goodness as medical purposes. The abusing of drugs has an impact on its takers such as severe depression, weight loss, panic attacks, thoughts of suicide and much more. The history shows that the drug has been used to change the sanity. Some individuals believe by using the drugs, they can deal with issues beyond sanity, resolve conflicts, and gained new awareness or perception of their lives. However, the reality of drugs uses going to work for us from using the positive sense. People with high addiction to drugs, also have the tendency to rely on passive and destructive drug use. Their nervous system will become less functional and individuals who are addicted will also be less able to work actively, constructively and interesting [15].

Various programs have been done by the Government and NonGovernment throughout ten years' evaluation. Furthermore, several strategies and efforts is shown and conducted which taken place in many ways and implementation. But, the rate of drug addicted person increase day by day and cause of social problems to happen such as bullying, raping, and stealing, fighting each other and sexuality arises. The increment of the criminal cases spreading in the society has created an uncomfortable and dangerous condition to women especially $[16,17]$. The aim of this study is to identify the rate of drug addicts according to several components which affects the increment of drug addiction in Terengganu. The study is considered as the best way of raising awareness among the community in order to know the negative sides of drug addiction and stay away from drugs.

\section{Methodology}

Various methods were used in completing this research. This study used several methods consisting of Descriptive Statistics Analysis using XLSTAT, secondary data and literature review. Methods are the one of the important component in collecting and researching the data through the evidences.

Firstly, this study used a Descriptive Statistics Analysis using XLSTAT from secondary data. The secondary data usually serves as the data documentation or report data available. The result of the drug addicts is analyzed from AADK information and considered as the secondary data that used in the study. Lastly, literature review used in the study to defined and discusses as critical discussions.

\section{Results and Discussion}

\subsection{The Number of Drug Addicts According to the Dis- trict in Terengganu, Malaysia}

According to the result in Figure 1, during the year of 2010, the highest number of drug addicts is located in Kemaman with 744 drug addicts while the lowest number is in Setiu with no drug addicts recorded. Besut is the second district of having drug addicts with 608 of drug addicts and followed by Kuala Terengganu, Marang, Dungun and Hulu Terengganu with 559, 264, 122 and 80 of drug addicts respectively. On 2011, Kemaman has increases the number of drug addicts into 974 of drug addicts and followed by Hulu Terengganu, Besut, Dungun, Kuala Terengganu, Marang and Setiu with $358,338,307,164,155$ and 147 of drug addicts respectively.

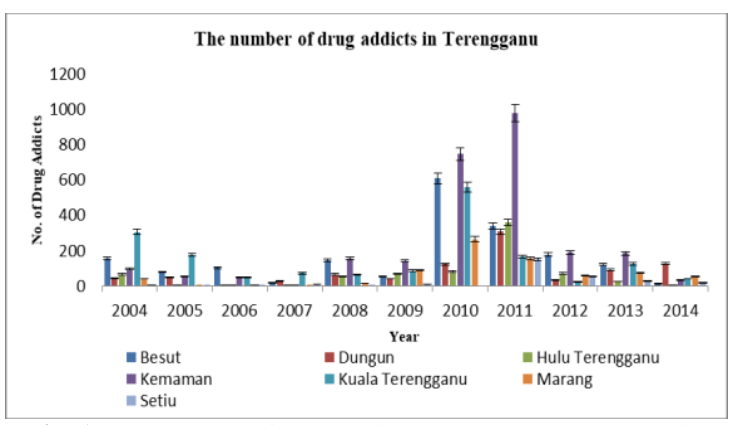

Fig. 1: The number of drug addicts in Terengganu, Malaysia.

Based on this study, Figure 2 shows the Box plots of drug addicts in Terengganu, Malaysia. Kemaman is recorded as the most critical district in Terengganu for drug addiction which it increases for four years and starts to decrease in 2013. Meanwhile, the least of drug addiction for districts in Terengganu is Setiu when it consists of small number of drug addicts among the years. The moderate of districts for drug addiction is Marang when it has the number of drug addicts mostly the same.

Based on the statistic of National Anti-Drugs Agency (AADK), a number of 188 drug addicts in Kemaman have been in 2012. This is because of Kemaman had the highest number of drug addicts from all district in Terengganu. then followed by Besut, Hulu Terengganu, Marang, Setiu, Dungun, and Kuala Terengganu with $177,70,56,53,33$ and 22 of drug addicts respectively. The data shows the decrement of the number for drug addicts started from 2012 to 2014. In fact, Kemaman has reduced the number of drug addicts a lot. However, it still had the highest number of having a lot of drug addicts in 2013. From the observation of AADK's officer, Kuala Terengganu is the second district which has the higher number of drug addicts. Meanwhile, Setiu which had no drug addicts in 2010 shows an increment starts from 2011 and get slightly decrease in 2012. During the year of 2014, Kemaman did not hold the title of the worse district for drug addiction because Dungun has gone ahead with the highest number of drug addicts was 125 and followed by Marang, Kuala Terengganu Kemaman, Setiu, and Besut and Dungun.

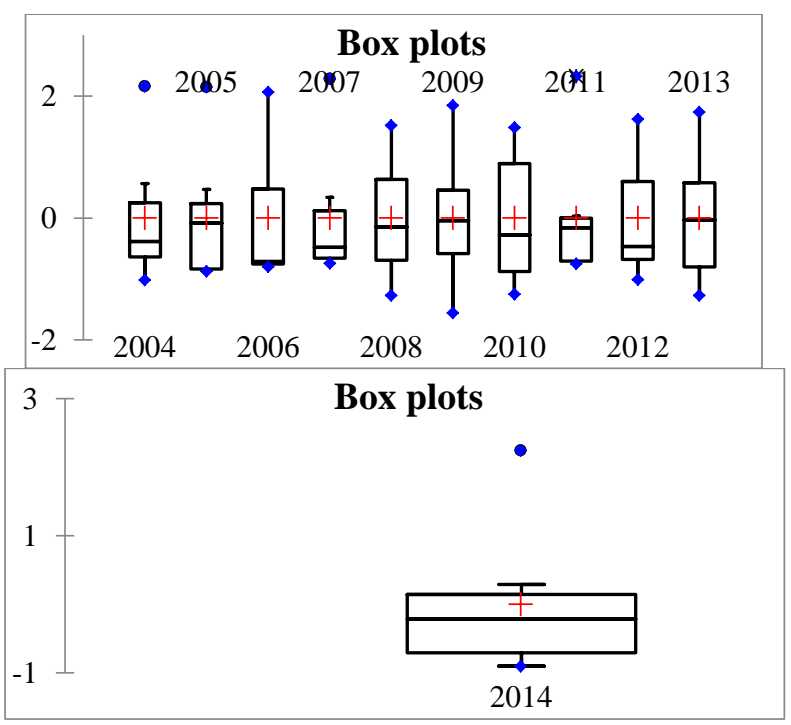

Fig. 2: Box plots of drug addicts in Terengganu, Malaysia. 


\subsection{The Number of Drug Addicts According Gender in Terengganu, Malaysia}

Figure 3 shows the number of drug addicts in Terengganu according gender. Male is the highest number of drug addicts and it keeps arising from 2010 to 2014. In fact, female is the minorities involves in drug addiction.

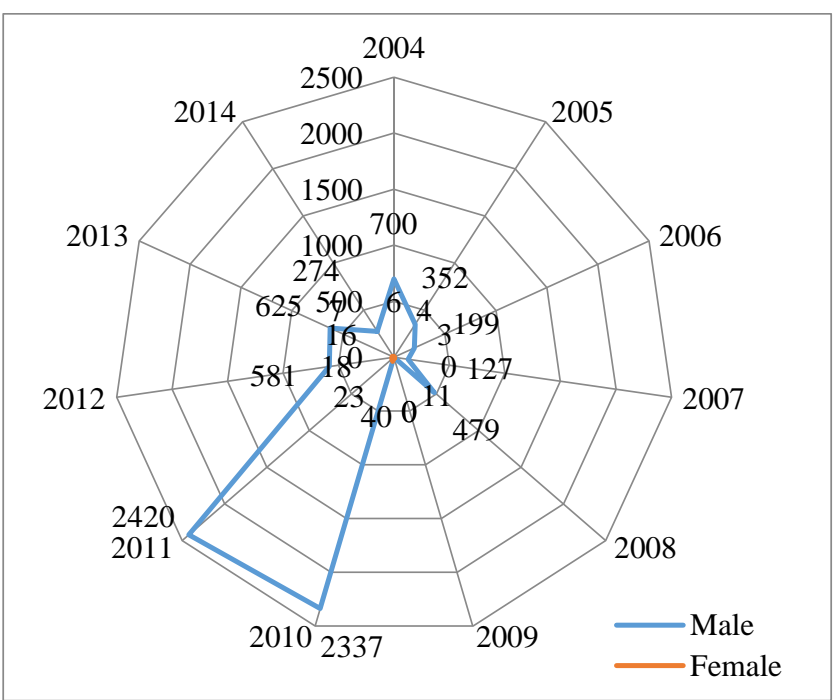

Fig. 3: The statistics of drug addicts according gender

During the year of 2010, male is the highest number of drug addicts which consists of 2337 and female with 40 of drug addicts. In 2011, the number for male drug addicts increases slightly in about 83 people more and become 2420 drug addicts while female has 23 drug addicts. The number of drug addicts for male has been decreased a lot which it turns into 581. Based on the statistic, the number for drug addicts has decreased in five years is representing female. Started from 2012, the number of drug addicts which represent male increases a little bit with 625 drug addicts. In conclusion, gender for male represents the highest number involves in drug addiction rather than female.

\subsection{The Rate of Drug Addicts According Ages in Ter- engganu, Malaysia}

Based on figure 4, age of 20-24 is the highest rate of age that involved with drug addicts. The rate in years 2011 increase, but it keeps decreasing in years 2012 until 2014. The middle rate is age 25-29. The lower rate is age 13-15 that shows in years 2010 only 4 person involved and in years 2011, the rate increasing but in next years it keeps decreasing until years 2014.

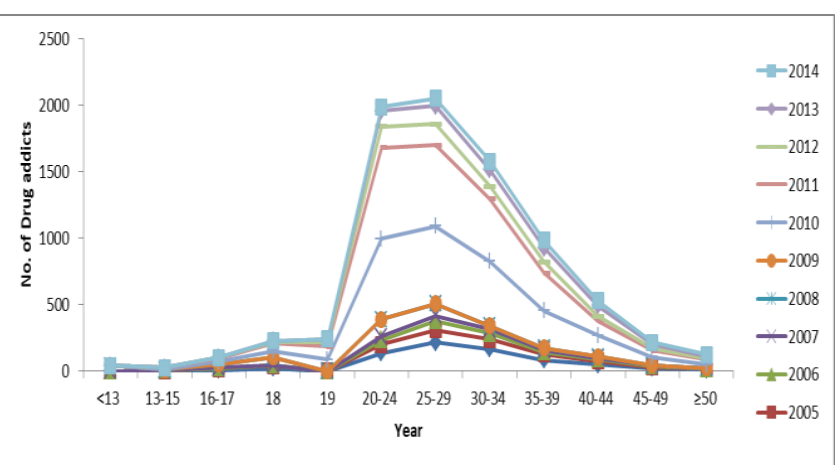

Fig. 4: Table shows the age of drug addicts involve in drug abuse in Terengganu

Based on the result of the study on the identification of drug addict rates, it shows that the highest age that involve with drug addict is age of 20 until 24 years old. In years 2010, people are involve with drug addict in this year is 602 people, 2011 with 686 people, 2012 with 159 people, 2013 with 137 people and 2014 with 54 people. As we can see, in years 2012 this age increases as many as 80 people but next year it decreasing until year 2014. It shows that adolescence is the highest that involve with drug addict. Adolescents are a synonym for drug abuse compared to other age groups. Young people are more tend to use drug compared elderly because of experience [18]. Then, it is followed by age 25 until 29 years old. In years 2010, rate of age 25 until 29 is 584 and it increase in years 2011 to 607 but decreasing in years 2012 with 161 people, 2013 with 137 people, 2014 its about 54 people.

Next, the rate of age 13 until 15 is the least age involved with drug addict. It shows that in 2010 there were 4 people involved, in 2011 there were 8 people and in 2012 only 1 person involved while in 2014 there was no involvement. Based on research 'Yayasan Perlindungan Jenayah Malaysia' found that most of the drug users in the country began to recognize the drug between the ages of 13-15 years and 71 per cent of new addicts of young people between 1939 years. As we can see, the number of the overall age is increasing in years 2011 and in the next year it keeps decreasing until year $2014[16,18]$. Furthermore, the highest risk of age that involve with drug addict is age 20 until 24 years old. Its mean young people mostly involve with this research. Therefore, government and NGO should play their part to prevent more young people from engaging with drugs. Lastly, the lower age that involve is age 13 until 15 years old. This is showed that, adolescents between 13 to 15 years less involved with drug addiction.

\subsection{The Number of Drug Influence According Factors in Terengganu, Malaysia}

Figure 5 shows the factors of drug influence. The highest factor of drug influence is peer influence. Factors of peer's influence in years 2010 highest, but it keeps decreasing in next years of 2011 until 2014. Peers influence is the major factor of drug influence at Terengganu then followed by middle factors of curiosity. In years 2011, curiosity's factor is highest than years 2010 but it decreases in years 2012 until years 2014. The lower factor is enduring pain/body defence in years 2010 lower than 2011 and its increase in years 2012 until 2014.

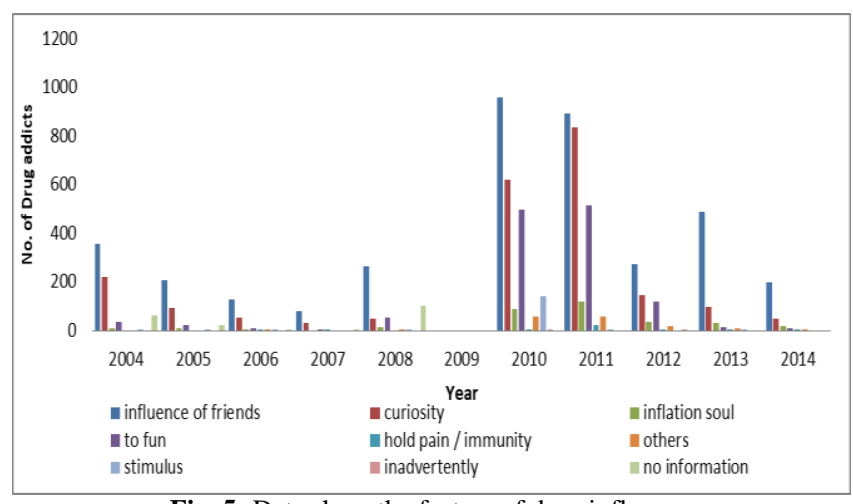

Fig. 5: Data show the factors of drug influence

Besides that, the results of the study have found that most of the drug addicts that involve is because of peer influence. Peer influence can be a negative site for adolescence. At this level (young people), they cannot think clearly because they only care about to be fun with their friend. In years 2010, peer influence results highest compare than years 2011. After that, it keeps decreasing in years 2011 until years 2014. The Curiosity factors in years 2010 with 621 people and increasing in next years with 683 people, in years 2013 with 97 people and years 2014 with 50 people. This factor is the second highest rate that give influence to people that involve with drug addict in Terengganu. Based on years 2011, people who involve on this year are increase as much as 216 people. It is increased a lot but for the next years it decreasing until 
years 2014. The rate of involvement due to depression shows that in 2010 there were 89 people, 2011 consisting of 118 people, 2012 with 21 people, and 2013 with 7 people while in 2014 there were 1 people. In 2011, the participation rate rising but it decreased in subsequent years. Next is fun factor and enduring pain or body defence. The result shows that in year 2011 increasing but still decreasing in next years until year 2014 .

\section{Conclusion}

In a nutshell, the number of drug addicts in Terengganu is studied in this article and be categorized by four aspects. The data has been discussed according four aspects which are by district, gender, ages and factor of drug influence. The most crucible district of having a lot of drug addicts is Kemaman. It is known by people that gender of male is the highest number who involves in drug addiction rather than female. Besides that, the highest rate of age that involve with drug influence is 20 until 24 years old. The major factors tend to be engaging in drug influence is a peer influence. Thus, all the results show the number of drug addicts has decreased. In conclusion, all parties need to know the tremendous drug problem in the state of Terengganu not only the state of Terengganu but also in Malaysia. This is so that the problem of drug can be reduced and make Malaysia a nation free from drug debris that can endanger everyone.

\section{Acknowledgement}

The authors acknowledge to UniSZA for Scholarship under research grants: UniSZA/2017/SRGS/17) - R0019-R017. Special thanks are also dedicated to National Anti-Drug Agency (AADK) for cooperating in providing the information that we need to complete this study, East Cost Environmental Research Institute (ESERI), UniSZA and Universiti Kebangsaan Malaysia (UKM) for the support, advice, and guidance for this study.

\section{References}

[1] Razak, D. A. (2004) Dadah: Senario sejagat yang membimbangkan. Retrieved, (18 April 2017). http:/www.adk.gov.my.my/rawat5.html.

[2] Ali, N. A. M., Mohamad, M., Muhammad, N., Yusoff, H. M., \& Omar, N. (2016) "The Impact of Social Climate on Life Satisfaction of Drug-Abuse Inmates in Malaysia Prison," IJABER, 14, 9453-9464.

[3] Zhang, R. (2017). The stress-buffering effect of self-disclosure on Facebook: an examination of stressful life events, social support, and mental health among college students. Computers in Human Behavior, 75, 527-537.

[4] Juita Ghazalie \& Osman Ali. (2006) Drug addiction and HIV infection amongst male in Malaysia, 1994. Drug addiction and HIV infection amongst male in Malaysia, 1994. Jurnal Kesihatan Masyarakat, 12(1), 1-8.

[5] Toriman, M. E., Abdllah, S. N. F., Azizan, I A., kamarudin, M. K. A., Umar, R., \& Mohamad, N. (2015). Spatial and Temperoral Assessment on Drug Addiction Using Multivariate Analysis and GIS. Malaysian Journal of Analytical Sciences, 19(6), 1361-1373.

[6] Othman Z. (2015). Penyalahgunaan Dadah Sebagai Ancaman Keselamatan. Malaysian Journal of Society and Space, 11 (13), 6071.

[7] Mohamad, M., Kamarudin, M. K. A., Juahir, H., Ali, N. A. M., Karim, F., Badarilah, N., ... \& Ridzuan, M. S. M. (2018) Development of Spatial Distribution Model using GIS to Identify Social Support Index Among Drug-Abuse Inmates. International Journal of Engineering \& Technology, 7(2.15), 1-7.

[8] Chaney, R. A., \& Rojas-Guyler, L. (2015). Spatial patterns of adolescent drug use. Applied Geography, 56, 71-82.

[9] Hasnah Bibon \& Mohd Hatta Md. Ramli, (2006) Knowledge, attitude and practice of prevention towards HIV/AIDS amongst health personnel in Tapah Hospital, Perak, 1996. Jurnal Kesihatan Masyarakat, 12 (1), 32-43.

[10] Brownstein, J. S., Green, T. C., Cassidy, T. A., \& Butler, S. F. (2010). Geographic information systems and pharmacoepidemolo- gy: using spatial cluster detection to monitor local patterns of prescription opioid abuse. Pharmacoepidemiology and drug safety, 19 (6), 627-637.

[11] Sikkens, E., \& San, M. Van. (2015). It's a hard knock life the survival strategies of Dutch Mulas in Peruvian prisons. Crime Law Soc Change, (63), 121-135.

[12] Ibrahim F, Samah B. A., Talib M. A. \& Sabran M.A. (2012), Penagih Dadah Dan Keadaan Berisiko Tinggi Kembali Relaps. Journal of Social Science and Humanities, 7(1), 43-54.

[13] Harun L. M. (2004), Penerokaan Gaya Hidup Penagih Dadah: Perspektif Teori Psikologi Individu. Pertanika J. Soc. Sci \& Hum. 12(2), 111-120.

[14] Akers RL (1992) Linking Sociology and Its Specialties: The Case of Criminology, Social Forces, 71(1), 1-16.

[15] Field T. S., Gurwitz J. H., Harrold L. R., Rothschild M. D., DeBellis K. R., Seger A. C., Auger J. C., Garber L. A., Cadoret C, Fish L, Garber L. D, Kelleher M., Bates D. W. (2004), J Am Geriatr Soc, 52, 1349-1354.

[16] Ibrahim F (2014), Penglibatan Remaja Dalam Penyalahgunaan Dadah: Analisis Tahap Perhubungan Dengan Rakan Sebaya. Jurna Pembangunan Sosial, 17, 71-85.

[17] Bistamam M. N., Ahmad A., Noor A. M., Jusoh A. J., Mustafa M. B., Ismail N., Jais S. M., Rohaizad F., \& Idris M. N. (2015), Profil Tingkah Laku Remaja Berisiko Mengambil Dadah. Jurnal antidadah Malaysia, 9(1), 23-34.

[18] Tunggak B., Hashim S., Mohamad N. A. \& Ali M. (2015), Faktor Risiko Belia Terlibat Dalam Penyalahgunaan Dadah dan Cadangan Penyelesaiannya Menerusi Model Pembangunan Belia Muslim Terpimpin. Jurnal Antidadah Malaysia, 9(1), 67-87. 